\title{
Review on success factors of waqf information management system in Malaysia
}

\author{
Norjansalika Janom ${ }^{1}$, Mohd Zairul Izham ${ }^{2}$, Fairuz Suraya Mansor ${ }^{3}$, Syaripah Ruzaini Syed Aris ${ }^{4}$, \\ Nor Shahniza Kamal Bashah ${ }^{5}$ and Noor Habibah Arshad ${ }^{6}$ \\ 1,3,4,5,6Faculty of Computer and Mathematical Sciences, Universiti Teknologi MARA, Malaysia \\ ${ }^{2}$ Aizach Niaga Sdn Bhd, Shah Alam, Malaysia
}

\begin{tabular}{l} 
Article Info \\
\hline Article history: \\
Received Jan 27, 2019 \\
Revised Apr 28, 2019 \\
Accepted May 18, 2019 \\
\hline
\end{tabular}

Keywords:

Information system

Islamic management

Success factor

Waqf information management

\begin{abstract}
Waqf is one of the important economic instruments in Islam. Waqf is known as an endowment consist of donating a building, a sum of money or plot of land for charitable purposes. Various relevant aspects with the field of waqf have been studied and debated by scholars in the area of socio-political studies, economic, accounting as well as waqf information management system development. Current research findings have shown few glaring issues in terms of the difficulty to distribute waqf benefits caused by incomplete file information, transparency of waqf documentation, lack of detailed information about waqf assets and the requirements to provide timely and sufficient information to the related stakeholders. Thus, this study explores conceptual model of integrated success factors of Waqf information management system from few literature analysis. The conceptual success model that consists of activities, relationships, relative advantage, compatability, triability, image, visibility, result demonstrability, voluntariness, complexity and trust have been used to demonstrate the Islamic and technology concepts of waqf information system. Thorough review from several research works will help to understand the gaps in the information system management related to the state waqf agencies in Malaysia. The findings of the above issues prove on the need to identify the success factors of waqf information system management thus, helps to ensure the success development of the system. The findings should be of great interest to both researchers and practitioners.
\end{abstract}

Copyright $\odot 2019$ Institute of Advanced Engineering and Science. All rights reserved.

\section{Corresponding Author:}

Norjansalika Janom,

Faculty of Computer and Mathematical Sciences,

Universiti Teknologi MARA,

Shah Alam, Selangor, Malaysia.

Email: norjan@tmsk.edu.my

\section{INTRODUCTION}

Waqf is known as an inalienable charitable endowment under Islamic law, which typically involves donating a building, plot of land or other assets for Muslim religious or charitable purposes with no intention of reclaiming the assets. Based on the history, the first waqf was the construction and development of Quba Mosque in Medina, Saudi Arabia, followed by the construction of Prophet's Mosque also in Medina, during the hijrah of the Prophet in 622m [1]. Waqf also showed a significant role in the development of Islamic and state civilizations as evidenced in the long history of over 600 years of Turkish Osmaniah Empire (1299-1923). Nowadays, waqf has proven to be beneficial to the people and to finance public expenditure including funding for the development of mosques, graves, hospitals, schools, orphanages, warehouses, bakeries, factories and other charitable, educational or religious foundations [1-3]. In Malaysia, the total land area of waqf is $11,091.82$ hectares in the whole country which been utilized social financing and economic 
development. Until 2016, about 23,771 (0.21\%) hectares of land have been developed and generate value in terms of providing retail space, shophouses, hotels, dialysis centers, orphanages, with total estimation value of RM111,413,889.85 [4]. Various aspects have been studied and debated by scholars relating to waqf fields such as socio-political studies [5], economics [6], waqf accounting and management [3] business models for waqf land [7] and waqf education plan [8].

Waqf is a complex process which involves elements such as donor, subject matter of waqf and various beneficiaries that require difficult and lenghthy operation, and legal procedures. The establishment of proper information systems can help organisation to manage and administer the process procedures better. Since information systems are considered as vital tools in today's competitive environment, the usage and its implementation have become major concern in most organisations. The study related to the waqf information management systems need and its development also have raised a lot of attention among researchers in Malaysia [9-10]. Looking at the significant needs of waqf information management systems, this research intends to review recent works of waqf information systems success factors through focusing on the elements and values created for the organization in Islamic sector. Thorough review from several research works will help to understand the gaps in the information system management related to the state waqf agencies in Malaysia. From the review analysis, the waqf information system success factors conceptual model was developed.

\section{HISTORY OF WAQF IN MALAYSIA}

The history of waqf in Malaysia is claimed to have existed more than eight hundred years ago, since the Arab traders brought Islam to the Malaya during the tenth century [11]. This is evidenced by Terengganu's inscription dated 13th century, which is also the earliest recorded record of the presence of Islamic syari'at in Malaya [12-13]. However, there is no written document on the establishment of the first waqf institution in Malaysia before the nineteenth century as stated above, except the establishment of the Capitan Kling Mosque in Penang in 1801, followed by a waqf by an Acehnese Relatives, as well as in Penang [14]. Meanwhile, [15] argued that the history of waqf in Malaysia can be detected over the past hundred years in accordance with the document on the first waqf practice seen in the "Endowment Prevention Enactment 1911" which enacted in the state of Johor. With regard to the goal, at the beginning of its development, education was the main goal of waqf developed in Malaya especially in Terengganu. This is evidenced by a waqf news of the nineteenth century by Sultan Umar who stated that the purpose of waqfnya was to develop education and dissemination of knowledge to the community [13].

From the aspect of managing waqf, in the old days, Muslims who want to do waqf need to meet the village chief or the Penghulu who will indirectly become the trustee of the waqf. Thus, usually no waqf record is made because they are based only on verbal transactions [16]. Problems will occur when Penghulu dies and is replaced by other people. Some heirs sometimes do not declare a waqf property but instead use it as their private property [17]. In other words, the practice of waqf by Muslims in Malaya is not well documented. Community leaders who are directly involved with Islamic affairs such as Qadi, Imam, even village chiefs or certain community or community committees such as the Masjid Committee, are appointed to administer and manage waqf [18]. They act as trustees or Mutawalli who responsible on the enforcement of Islamic law which is enforced by the states.

The absence of legal provisions for the administration of waqf in the past resulted in the administration of land or waqf property is managed inefficiently and not systematically. People who intend to give their lands are made orally with the presence of two witnesses. The process is followed by the appointment of a waqf manager to administer and manage the land. The absence of the provisions of this law also led to the appointment of waqf managers on selected individuals who were trusted and respected in local communities such as local leaders, religious scholars, religious teachers, priests, village chiefs and mosque committee members eventhough some of them were unable to administer, manage and develop waqf land. This led to the occurrence of several cases including the act of transferring land titles to their names [15]. In other cases, some lands which were supposed to be registered as waqf land, were registered as eternal property under the name of the pawaqf due to the failure of the manager to record the waqf property systematically. The the administration and management of non-systematic land and waqf property is continued until the state islamic council (MAIN) was established and the state administration of islamic law enactment (administration of islamic law) was introduced.

On 1952, Selangor was the first state that introduced MAIN as a waqf property manager (Selangor Islamic Law Administration Enactment, 1952). The initiatives were followed by Kelantan in 1953, Terengganu in 1955, Pahang in 1956, Melaka in 1959, Penang in 1959, Negeri Sembilan in 1960, Kedah in 1962, Perlis in 1963, Perak in 1965, Federal Territory in 1974, Sabah in 1977, Johor in 1978, and Sarawak in 2001 [15]. 
MAIN is then entrusted with the power to act as the sole trustee of all properties and lands of waqf in Malaysia. But the irregular administration and management of waqf in the past particularly related to the absence of a written record of a waqf land and the failure to register a land of inheritance, has left the MAIN with two major problems to be resolved. First, MAIN has difficulties in identifying the actual number, size and location of the waqf land. Second, MAIN also has a problem in claiming the right to be the sole trustee of an unregistered waqf. The problem became increasingly complex when the appointed waqf manager had died and the heirs claimed that the property or land was not recognized as a waqf by their parents or family members [19].

\section{GAPS RELATED TO WAQF INFORMATION MANAGEMENT SYSTEM IN MALAYSIA}

Although waqf has begun to show good growth in Malaysia, the past survey as presented above finds some gaps need improvement including in relation to information management. The findings are reinforced by the study conducted by [20] in relation to the implementation of istibdal mechanisms for waqf land involved with recruitment by the government in Terengganu state. They found at least 94 lots of waqf land involved with land acquisition by State Authorities since 1951. Their findings also found that significant weaknesses are related to records or land acquisition information. The party managing the waqf land does not list the entire waqf land involved with the acquisition. Meanwhile, for the special waqf of the mosque and waqf zuriat, the benefits are difficult to be distributed to beneficiaries for involving several mosques and other heirs. Among the causes are lack of staff and incomplete file information.

The study of [20], also indicates the problem of information management. They identified the waqf administration problem faced in the states of Peninsular Malaysia is in connection with the transparency of the waqf documentation. Naturally, MAIN should be aware of the information requirements required by the respective waqf holders [21]. Meanwhile, interviews with selected MAIN officers in Malaysia also show no detailed information on waqf assets [22]. The disadvantages of managing this waqf information are contrary to the principle that the public need to provide the information they need to know more about how and why they should donate their waqf [9].

\section{MALAYSIA WAQF INFORMATION MANAGEMENT SYSTEM}

Information Systems are referred to as socio-technical type systems [23]. This means that the information system is a combination of elements such as humans, data, hardware, software, networks and procedures that are interconnected with each other to provide useful information to users [24]. In Malaysia, awareness of the need for a waqf information management system has begun to be found. The study by [6] states the need for the Waqf information management system to be established to support projects that help sustain the waqf. Preliminary studies also found that several research related information systems for certain waqf were conducted. A group of researchers led by [25] develops web-based tree management model and information system. This system is developed to assist management of waqf which is expected to increase income from the agricultural sector [26] anyway develop a system of cash e-waqf according to the information system engineering methodology. The system has been specifically designed for waqf administration by using web-based technology where it is alleged to be able to provide access to system users either from within or outside the organization. The main purpose of this system is to develop to facilitate the administration and management of waqf to produce reports according to the specifications of certain reports and statistics, whether based on monthly, according to the list of applicants, by the amount of money earned and other reports, as well as generate graphical information for each such report. This will also enable the waqf management to make certain analysis on the cash waqf application made from to-day to further improve the quality of cash waqf services to users of e-waqf cash system.

Besides, [25] and [26] have listed the research they have undertaken on the waqf information management system namely Pontian District Waic Information System Development in 2000, Geographic Information System for the Management of Waqf Information System in 2003 and Property Information System Waqf Land for the Johor Islamic Religious Council in 2004. In Selangor, a preliminary survey found that the Selangor Waqf Corporation (PWS) has taken the initiative to create the Waqf Selangor Online which began to be used in November 2016, among which the system's function is the acceptance of General Waqf via online payment using the Financial Process Exchange (FPX). In addition, this system enables the pawaqf to register as a user for the purpose of checking the transaction, updates and some other functions. 


\section{WORLDWIDE WAQF INFORMATION MANAGEMENT SYSTEM}

The above literatures have indicated some gaps in the management of waqf information in state of waqf agencies in Malaysia. To address this, it is urgent to develop an integrated and comprehensive waqf management systems that able to manage waqf information more effectively. Although various waqf information management systems have been developed by various waqf agencies in Malaysia as presented above, however, the developed system is particularly relevant only for certain waqf projects such as the agricultural sector [25] and the e-cash waqf system [26]. In addition, previous studies show that existing systems can not provide the information needed by stakeholders [20]. It is, however, unfair to blame anyone for this weakness as the history of management of waqf information in Malaysia is considered as relatively new. Thus, specific study to understand the needs and requirements for the integrated and comprehensive waqf management system that can be used by various types of waqf is needed. For the purpose of developing a system, not only technology aspect, but also social aspects need to be given careful attention. The success of the information system depends on various socially constructed factors which are subject to the views of the stakeholders. Even [28] proved that one of the critical factors of an information management system is the culture and environment of this system.

In addition, taking into account social factors, the development of information systems is also necessary to comparative studies not to mention in developing a complex waqf information system. This waqf information system is complex because it involves various entities such as pewaqf, mutawalli, waqf property, form of waqf property development and beneficiary waqf. A comparative study with specific waqf information management systems such as Turkey can be carried out. The history of Turkish waqf should be examined profoundly because it has a history beginning from the first waqf registered in 1048 [29]. As of 2011, there are over 35,000 waqfiyya or waqf deeds [30]. Ability to administer waqf information hundreds of years is expected due to the tradition of information management which is reliable [31].

This effective tradition needs to be identified because the success of an information management system depends not only on technology, but social and environmental factors are also one of its determinants. In addition to the waqf information management tradition in Turkey, there is also a special software system that has been developed to archive historical certificates owned by 41,720 waqf foundations in parallel with the perspective of modern record keeping [32]. Other written documents (warrants, deeds, certificates, etc.) since the Seljuk and Uthmaniyyah periods have been collected or scanned and recorded in microfilms and digital archives included in the Foundation Archive Management System (FAMS) project [30].

In terms of organization, The Directorate General of Foundations is a government agency responsible for managing and auditing waqf foundations that existed since the Ottoman Empire until [30]. Institutions set up on May 2, 1920 administered estates and carried out rehabilitation of about 18,500 historic buildings and 67,000 estates and manage about 38,000 workers [32]. Data and information from a comprehensive comparative study are expected to assist in the development of conceptual model and further development of an integrated waqf management system.

\section{THE DEVELOPMENT OF WAQF MANAGEMENT SYSTEM SUCCESS FACTORS MODEL}

Several research works have been performed for the determination of reasons behind the success of Information System project development specifically related to Waqf Information Management System. Since there is limited research focusing on the success factors of Waqf information system, two similar Islamic concepts have been identified as a main reference models to be linked with the critical success factors of waqf information management system research as below:

\subsection{Adoption of zakat corporation information system development}

In adoption of zakat corporation written by [34], the researchers stated that there are nine important pillars of zakat adoption model which are relative advantage, compatibility, result visibility, trialability, result demonstrability, complexity, image, vulnerability, and trust. This work proposes a model for a better understanding of the buildings underlying the adoption of the Zakat collection in Malaysia and which to some extent can be generalized in other Islamic concept for example waqf. The model used was adopted and considered as the extension of the existing behavioural models like Integrated Model for IT adoption (IDT) and Technology Acceptance Model (TAM). These new model structures were then validated in the Muslim community of Zakat payers.

\subsection{Integrated Waqf Reporting Systems}

This research is also gathered through Integrated Waqf Reporting Systems (IWRS) framework by [35]. The authors stated that in any of the information system framework model, there would be values created for the organization. The values are activities, relationship and interactions. These three values- 
created played big impact for the waqf organization. Using the basic principle of value ceated, waqf institutions can be more flexible in designing their own organizational reports with meaningful and relevant information for users. The reporting approach requires the preparers of the reports to collect all relevant information and link it to key drivers that create value added for the organization.

Good governance also mediates various interests in order to reach a broad consensus on the best interests of the group and, where possible, on policies and procedures. The waqf institution's governance will only be considered successful if it manages to fulfil its duty with accountability through transparency in its operation, in addition to waqf reporting.

The IWRS ' basic concept is to explain how a waqf institution creates value over time. Waqf institutions could create value through interaction with the external environment in which the institutions operated, through relationships with stakeholders which are government, beneficiaries, waqf board, donors and potential donors, the public and, ultimately, Allah, and dependent on a variety of resources of financial, manufactured, intellectual, human, social and natural. This is also allign with the research study of [36-39], which emphasized that the external and internal environments of the organization can have impact on the success of any information system projects. In order to accomplish healthy environment of a project, the socio-economic issues and the organizational structure can affect the efficiency of the project [40-41]. Considering the similarity of Islamic and information technology concepts that been emphasized in both models, the adoption of zakat corporation information system development model and IWRS model have been combined and used to produce the conceptual model of integrated success factors for waqf information system management as shown in Figure 1.

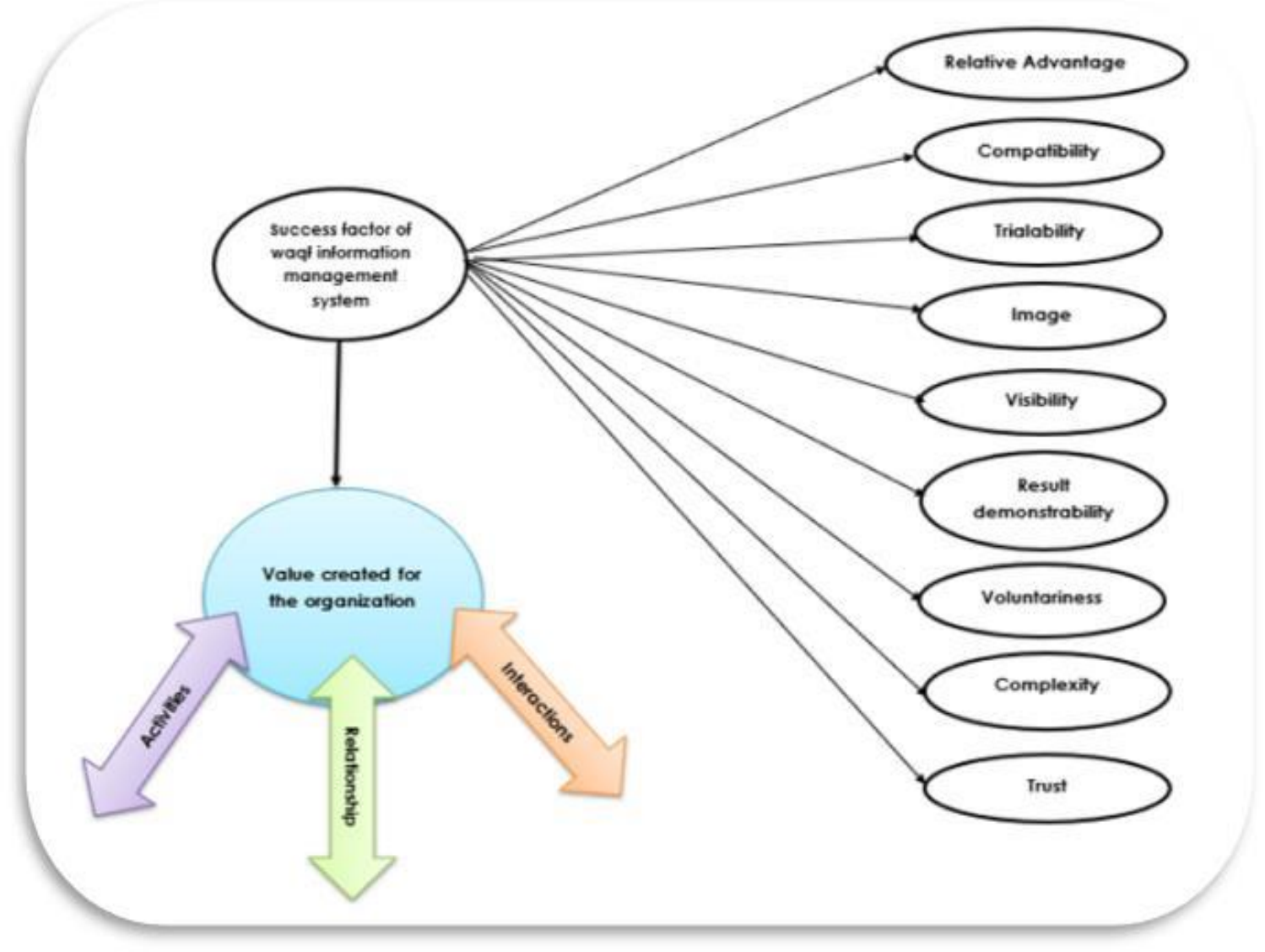

Figure 1. Conceptual model of integrated success factors for waqf information management system

As shown in Figure 1, the conceptual success model that consists of activities, relationships, relative advantage, compatability, triability, image, visibility, result demonstrability, voluntariness, complexity and trust underlie much of the existing literature on information system success and Islamic information system concepts of that also been mentioned in [34-42]. Table 1 provides futher explanations of each factor. 
Table 1. The Components of the integrated success factors model of waqf information management system

\begin{tabular}{|c|c|c|}
\hline Components & Description & Sources \\
\hline Activities & $\begin{array}{l}\text { Every waqf institution should identify its sustainable business model and activities to achieve the } \\
\text { specific objectives of the waqf. The short term and long term planned activities help the } \\
\text { sustainability of the waqf institutions and forms the foundation for its information system } \\
\text { strategies. }\end{array}$ & $\begin{array}{l}{[35] ;} \\
{[41]}\end{array}$ \\
\hline Relationships & $\begin{array}{l}\text { The waqf institutions could create value through the interaction of information with the external } \\
\text { environments where the institutions operated. }\end{array}$ & $\begin{array}{l}{[35] ;} \\
{[40]}\end{array}$ \\
\hline Interactions & $\begin{array}{l}\text { The waqf institutions could create value through relationship with the stakeholders (the } \\
\text { government, the beneficiaries, waqf board, the donors and potential donors, and the public) and } \\
\text { dependent on various resources (financial, manufactured, intellectual, human, social and } \\
\text { relationship and natural). }\end{array}$ & $\begin{array}{l}{[35] ; \quad[40] ;} \\
{[42] ;[38]}\end{array}$ \\
\hline Relative advantage & $\begin{array}{l}\text { The emergence of the zakat or waqf collection of companies forced respective authority to } \\
\text { introduce a more efficient fund collection through online payment or through direct deduction } \\
\text { from the source of those who want to waqf. The advantages of collecting or paying waqf from } \\
\text { companies and individuals through Information System will be far exceed the cost of building the } \\
\text { system. }\end{array}$ & [34] \\
\hline Compatibility & $\begin{array}{l}\text { Compatibility refers to the extent to which an innovation is compatible with the well- known } \\
\text { values, beliefs, experiences, needs, social norms and practices of its users, taking socio-cultural } \\
\text { values and perceived needs into consideration. The compatibility of an innovation with the well- } \\
\text { known values, beliefs, experiences and needs of people have a positive effect on its } \\
\text { implementation. }\end{array}$ & $\begin{array}{l}\text { [39]; [42]; } \\
\text { [41]; [34]; }\end{array}$ \\
\hline Trialability & $\begin{array}{l}\text { Trialability is the extent to which an innovation can be tested before resources are used or the } \\
\text { extent to which the innovation can be experienced on a limited basis. An innovation that gives its } \\
\text { user the opportunity to test on experimental bases before adoption is likely to be adopted more } \\
\text { quickly. }\end{array}$ & [34]; [37] \\
\hline Image & $\begin{array}{l}\text { Image refers to the extent to which innovation is perceived to improve the rank of an individual } \\
\text { in his or her social system. The collection of corporate waqf provides a way for the donor to carry } \\
\text { out one of the fundamental teachings in Islam. Corporatization is also a vogue, and it embraces a } \\
\text { certain level of user progressiveness. }\end{array}$ & [39]; [34] \\
\hline Visibility & $\begin{array}{l}\text { This is the degree to which people in the organization can see others that use the system. The } \\
\text { general use of waqf collection by companies will enhance others to try it. The more visible the } \\
\text { company's waqf collection is, the more the others want to participate in it. }\end{array}$ & $\begin{array}{l}{[39] ;[42] ;} \\
{[34]}\end{array}$ \\
\hline $\begin{array}{l}\text { Result } \\
\text { demonstrability }\end{array}$ & $\begin{array}{l}\text { This refers to the tangibility of the results, including observability and communicability, of using } \\
\text { the innovation. If the outcome of the waqf operation is easily observed and easy for even lay } \\
\text { people to understand and explain, the possibility of accepting it is higher. }\end{array}$ & [34] \\
\hline Voluntariness & $\begin{array}{l}\text { Voluntary use is the extent to which the use of innovation is seen to be voluntary or free- will. } \\
\text { The donation or collection of waqf in Malaysia is not compulsive, although it is a state affair. } \\
\text { Payers are left to do this because they believe and devote themselves to their religion. Corporate } \\
\text { collection is therefore only to facilitate the payment of potential payers. }\end{array}$ & $\begin{array}{l}{[39] ;[42] ;} \\
{[34]}\end{array}$ \\
\hline Complexity & $\begin{array}{l}\text { Complexity refers to the easy understanding and application of an innovation or the risk } \\
\text { associated with its use. Some innovations are easy for the majority of people in a social system to } \\
\text { understand, while others are more complicated and will be adopted slower. Innovations that are } \\
\text { easier to understand are adopted faster. }\end{array}$ & [34]; [42] \\
\hline Trust & $\begin{array}{l}\text { Trust is faith when it's easy to feel unfaithful. It's to believe the incredible and to know the } \\
\text { unknown. Trust reduces the social complexity and perceived uncertainty of transactions by } \\
\text { increasing expectations of a positive outcome and perceived certainty about the expected trustee's } \\
\text { actions. In order to make these economic activities more rewarding, people try to avoid risks and } \\
\text { reduce this social complexity through the trust issue. }\end{array}$ & $\begin{array}{l}{[40] ;} \\
{[38]}\end{array}$ \\
\hline
\end{tabular}

\section{CONCLUSION}

History proves that waqf plays an important role in the development of the ummah through various economic and social developments. Recognizing the importance of trust that accompany the management of waqf property, it is the duty of the respective agencies to properly managed it so the benefits can be more visible and value created. Among the things that need to be emphasized are the information pertaining to the treasured property. Studies show some gaps in the management of waqf information of state waqf agencies in Malaysia including the inability to provide proper waqf information to the community and the failure to develop waqf land due to incomplete waqf property information. With the advanced information technology, an integrated waqf information management system should be developed. But to minimize the failure in developing the systems, studies on waqf information system success factors related to social and technology perspectives need to be carried out so that system risks and vulnerabilities can be avoided.

\section{ACKNOWLEDGEMENTS}

The authors would like to thank to Research Management Institute, Universiti Teknologi MARA, Malaysia for their funding support under LESTARI Research Grant with project code 600-IRMI/DANA 5/3/LESTARI (0136/2016). The paper also acknowledged the support given by Crowd Business and Innovation Research Interest Group, Faculty of Computer and Mathematical Sciences, UiTM Shah Alam. 


\section{REFERENCES}

[1] N. A. Mohd Puad, N. Jamlus Rafdi, W. S. S. Shahar, "Issues and Challenges of Waqf Instrument: A Case Study in MAIS". E-proceedings of the Conference on Management and Muamalah, CoMM 2014, May 2014.

[2] S. M Mahamood, "Waqf in Malaysia: Legal and Administrative Perspectives", Universiti of Malaya Press, Kuala Lumpur, 2006.

[3] A. A. A. Fayzee, "Outlines of Muhammadan Law", Oxford University Press, Delhi, 1974.

[4] A. Sanep and M. Nur Diyana, "Institusi Wakaf dan pembangunan Ekonomi Negara: Kes Pembangunan Tanah Wakaf di Malaysia", Prosiding PERKEM VI, Jilid, 138-147, 2011.

[5] M. Kahf, "Waqf and its sociopolitical aspects", Essential Reading in Contemprary Waqf Issue, CERT 2011, 2011.

[6] M. Kholid, R. Sukmana, K. A. Hassan, "Waqf Management through Sukuk Al-intifa'a: A Generic Model", Ninth Year AWQAF, vol. 17, 2009.

[7] N. Mohd Ali, R. Ahmad, and N. S. Ahmad Mahdzan, "The need of an effective business model for waqf land development in Malaysia”, The 20th International Research Conference on Business, Economics, and Social Sciences, IRC 2015, Dec 2015.

[8] N. Iman, "Waqf Untuk Kemandirian Pendidikan". Penerbit WADE, 2017

[9] M. Zakaria, M. Sabri Hassan and R. Abdul Latiff, "Pelaporan Wakaf di Malaysia: Mengenalpasti Keperluan Maklumat Pemegang Kepentingan”, Prosiding Persidangan Kebangsaan Ekonomi Malaysia ke-9 (PERKEM ke-9), 226-223, 2014.

[10] M. E. S. Abd Aziz, M. I Md. Raus, W. A. Wan Ahmad, M. M. Othman, M.H. Abdul Wahab. "Economics of Waqf of Tree Information Management System (WaTIMS): A Proposed WaTIMS Model for Practitioners and Future Researcher", 2nd World Conference on Islamic Thought \& Civilization Rise \& Fall of Civilization Contemporary States of Muslim Affairs, WCIT 2014, vol. 9789675480102,2014

[11] H. Yaacob, "Waqf History and Legislation In Malaysia: A Contemporary Perspective". Journal of Islamic and Human Advanced Research. vol.3. issue 6. 387-402. 2013.

[12] Ibrahim, "WAQF Accounting and Management in Indonesian WAQF Institutions: The Cases of Two WAQF Foundations", Humanomics, vol. 27, 252-269, 2011.

[13] T. Mahmood, "Waqf and its Implementation in Malaysia". Siri Penyelidikan Yayasan Islam Terengganu. 26. Percetakan Yayasan Islam, Terengganu, 2000.

[14] K. S. Nasution, "Colonial Intervention and Transformation of Muslim Waqf Settlements in Urban Penang: The role of the Endowments Board”. Journal of Muslim Minority Affairs. vol 22, issue 2, 299-315, 2002.

[15] C. Z. Ismail, N. J. Salim and N. J. Ahmad Hanafiah, "Administration and Management of Waqf Land in Malaysia: Issues and Solutions", Mediterranean Journal of Social Sciences, vol. 6, 2015.

[16] Y. Hisham, "Waqf History and Legislation in Malaysia: a Contemporary Perspective". Journal of Islamic and Human Advanced Research, vol. 3, pp. 387-402, 2013.

[17] S. Baharuddin, "Pentadbiran dan Pengurusan Harta Waqaf di Semenanjung Malaysia (The Administration and Management of Waqf Property in Peninsular Malaysia)". 91-116, 1998.

[18] N. Kamaruddin, "Isu Pembangunan Tanah Wakaf (Waqf Land Development Issues)". Dewan Bahasa dan Pustaka. Kuala Lumpur, 1992.

[19] M. Salleh, A.H., Muhammad, N.S. and Adham, K.A., Managing Waqf For Societal Well-Being. Pusat Penerbitan Universiti (UPENA), Shah Alam, 2014.

[20] R. Harun, Z. Mohamed Isa and N. Ali, "Preliminary Findings on Waqf Management Practices Among Selected Muslim Countries". International Conference on Economics Marketing and Management, pp. 5-7, Jan 2012.

[21] M. Zakaria, M. S Hassan., and R. A. Latiff, "Pelaporan WAQF di Malaysia: Mengenalpasti Keperluan Maklumat Pemegang Kepentingan”. Persidangan Kebangsaan Ekonomi Malaysia ke-9, PERKEM ke-9, 2014.

[22] R. Masruki and Z. Shafii, "The development of WAQF Accounting in Enhancing Accountability", Middle-east Journal of Scientific Research, vol. 13, 2013.

[23] Essays, UK, "Major Causes of Information Systems Failure Information Technology Essay", Nov 2013.

[24] M. E. Vermaat, S. L. Sebok, S. M., Freund, J. T. Campbell, and M. Frydenberg, "Discovering Computers: Tools, Apps, Devices, and the Impact of Technology", Boston: Cengage Learning, 2016.

[25] K. M. A. Hassanain, R. Sukmana and A. G. Ismail, WAQF and Socio-Economic Development, IIUM Press, 2018.

[26] M. M. B Othman, W. A. B. W. A Seman, M. H. B Abdul, M. I. Wahab, and M. E. S. A Aziz, "Peranan ICT Dalam Pembangunan Harta WAQF di Malaysia”, 2011.

[27] R. Harun, H. Abd Mutalib, R. Abdul Rashid and A. Murat, "Promotion as a Determinants for Waqf Awareness Among University", International Academic Research Journal of Social Science. Vol. 2. 95-99. 2016.

[28] B. P. Kaur and H. Aggrawal, "Exploration of Success Factors of Information System", International Journal of Computer Science Issues, IJCSI 2013, vol. 10, Jan 2013.

[29] M. Çizakça, "Awqaf in History and Its Implications for Modern Islamic Economies", Islamic Economic Studies, vol. 6, pp. 43-70, 1998.

[30] D. Demirhan, T. Susmuş and S. Gönen, "Cash Waqfs And Their Accounting Applications at The End of the 18th Century in The Ottoman Empire". Journal of Economics \& Administrative Sciences, pp. 1-21, 2012.

[31] M. Babacan, "Economics of Philanthropic Institutions, Regulation and Governance in Turkey". Journal of Economic and Social Research, vol. 13, pp. 61-89, 2011.

[32] S. Saduman, and E. E. Aysun, "The Socio-Economic Role of Waqf System in the Muslim- Ottoman Cities' Formation and Evolution”. Trakia Journal of Sciences, vol. 7, pp. 272-275, 2009. 
[33] T. Kuran, and S. Review, "Impact, and IT Limitations of the Waqf System with the Challenge of providing "public goods", vol. 35, pp. 841-898, 2001.

[34] M. B. Owolabi Yusuf, and A. Mat Derus, "Measurement Model of Corporate Zakat Collection in Malaysia: A Test of Diffusion of Innovation Theory", Humanomics, vol. 29, pp. 61-74, 2013.

[35] N. Mansor, A. Jamil, and A. Bahari, "Integrated Waqf Reporting System", International Journal of Accounting, Finance and Business (IJAFB), vol. 2, pp. 155-166, 2017.

[36] R. Burke, "Project management: planning and control techniques", 2013.

[37] N. A. Endut, N.S. Kamal Bashah, and S. Abdullah, "Critical Success Factors of Edge Implementation in DIGI Telecommunications", Proceedings of The International Conference on Business IT, BIZIT 2006, 2006.

[38] S. R. Hamidi, and K. Jusoff, "The Characteristics and Success Factors of an Organizational Memory of Information System”, Computer and Information Science, vol. 2, pp. 142-151, 2009.

[39] F. Mahmood., W. A. Wan Adnan, N. L. Md Noor, F. Mohd Saman, "Emotional Response Towards CulturalBased E-Government Portal Design Using Card Sorting Method", Communications in Computer and Information Science, i-USEr 2018, pp. 886, 2018.

[40] S. Md Sarif, S. R. Hamidi, B. M. Ramli, M. L. Anitawati, "The Influence of Organizational Factors in the Success of IT Project Management”, Indian Journal of Science and Technology, vol. 9, pp. 1-7, 2016.

[41] L. P. Leach, "Critical Chain Project management", Artech House, 2014.

[42] A. I. H. Suhaimi, H.A. Abd Rahim, F. Redzuan, W. A. R. Wan Isa, and W.A. Wan Adnan, "The Determinants of online Information Sharing Behavior Among Millennials in Malaysia", Advanced Science Letters, vol. 23, pp. 10568-10572, 2017. 